\title{
Desain Model Wisata Belajar di Kebun Binatang Gembira Loka Yogyakarta Sebagai Laboratorium Luar Kampus
}

\author{
S. Sujarwo ${ }^{1 *}$, Ibnu Samsi ${ }^{2}$, Lutfi Wibawa ${ }^{3}$ \\ ${ }^{123}$ Pendidikan Luar Sekolah, Universitas Negeri Yogyakarta. Jalan Colombo No. 1, \\ Karangmalang, Yogyakarta, 55281, Indonesia \\ * Korespondensi Penulis. Email: sujarwo@uny.ac.id \\ Received: 12 January 2017; Revised: 28 February 2017; Accepted: 20 March 2017
}

\begin{abstract}
Abstrak
Penelitian ini bertujuan untuk mendekripsikan desain model wisata belajar di Kebun Binatang Gembira Loka Yogyakarta. Penelitian tahap awal ini tersusun desain model wisata belajar di GL Zoo merujuk pada penelitian tindakan. Dari informasi yang diperoleh pada tahap pengumpulan data, selanjutnya peneliti mendesain produk yang berupa desain model wisata belajar, menyusun panduan kegiatan, panduan pendampingan, pelaksanaan dan refleksi. Untuk mendukung keberhasilan wisata belajar perlu adanya panduan yang dapat dijadikan acuan dalam kegiatan pembelajaran. Adapun komponen dalam desain model ini terdiri dari; (1) calon peserta, (2) memilih peserta, (3) Bentuk Kegiatan Wisata Belajar (penyambutan, bina suasana, tour to zoo, zona alam, pojok kreatif, permainan, dan refleksi), (4) Materi Kegiatan sesuai jenis kegiatannya, (5) media, (6) bahan Ajar, (7) penilaian, (8) sosialisasi program, (9) pelaksanaan program, (10) evaluasi program dan (11) pendampingan, Model ini dilengkapi dengan panduan kegiatan, panduan pembelajaran, dan panduan materi wisata belajar

Kata Kunci: desain model, wisata belajar, laboratorium luar kampus

\section{Design of Study-Tour Model in Gembira Loka Zoo Yogyakarta as an Outdoor Laboratory}

Abstract

The paper is aimed at describing the design of study-tour model in Gembira Loka Zoo Yogyakarta. This initial-phase research comprised the design of study-tour model in Gembira Loka Zoo which refered to action reseach. On the basis of the information gained from the data collection, the researchers designed the product in the form of study-tour model, arranged the guides of activities, accompaniment, implementation, and reflection. In order to support the success of study-tour, a guide which could be used as a reference in the learning activity is needed. The components of the model design consisted of (1) candidates of participant, (2) participants selection, (3) study-tour activity (welcoming, atmosphere building, zoo tour, nature zone, creativity corner, games, and reflections), (4) activity materials suitable to the types of the activity, (5) media, (6) learning material, (7) assessment, (8) program socialization, (9) program implementation, (10) program evaluation, and (11) accompaniment. This model was completed with guides on the activity, learning, and study-tour materials.
\end{abstract}

Keywords: design model, tourism learning laboratory campus affairs

How to Cite: Sujarwo, S., Samsi, I., \& Wibawa, L. (2017). Desain model wisata belajar di Kebun Binatang Gembiraloka Yogyakarta sebagai laboratorium luar kampus. Jurnal Pendidikan dan Pemberdayaan Masyarakat, 4(1), 90-10o. doi:http://dx.doi.org/10.21831/jppm.v4i1.12535

Permalink/DOI: http://dx.doi.org/10.21831/jppm.v4i1.12535 


\section{PENDAHULUAN}

Wisata belajar menjadi bagian yang tidak terpisahkan dari aktifitas yang dikembangkan oleh sekolah-sekolah formal, sebagai usaha menambah wawasan dan pengetahuan siswa sambil melakukan wisata. Rushforth et al., (2008), mengungkapkan study tours are by their nature educational, offering the participant a 'window on the world'. However whilst they are inspirational and a catalyst for debate or further study, they are also inevitably subjective sources of insight rather than formal evidence. Wisata belajar atau sering disebut dengan study tour yang menurut sifatnya merupakan aktifitas pendidikan, kegiatan ini menawarkan peserta untuk melihat jendela pada dunia. Kegiatan ini juga mampu memberikan inspirasi dan katalisator untuk mendiskusikan tentang masa depan yang membutuhkan studi lebih lanjut, lokasi wisata belajar juga merupakan sumber pasti subjektif dari wawasan daripada bukti formal.

Wisata belajar juga bisa diartikan sebagai sebuah aktifitas perjalanan oleh sekelompok orang untuk mempelajari sesuatu, seperti lokasi, budaya dan juga tradisi. Rodger (1998), mengemukan bahwa tourism atau pariwisata pendidikan dimaksudkan sebagai suatu program di mana peserta kegiatan wisata melakukan perjalanan wisata pada suatu tempat tertentu dalam suatu kelompok dengan tujuan utama mendapatkan pengalaman belajar secara langsung terkait dengan lokasi yang dikunjungi. Wisata Pendidikan merupakan suatu program yang menggabungkan unsur kegiatan wisata dengan muatan pendidikan didalamnya. Kebun binatang adalah tempat yang indah dengan sumber daya yang kaya bagi proses pendidikan yang memungkinkan peserta didik untuk menjelajahi dunia alam dan mempromosikan pengembangan konsep tentang hewan, ekologi, dan keanekaragaman hayati. Proses pembelajaran dan pengembangan ilmu pengetahuan ilmiah sangat memungkinkan dimulai di kebun binatang Gembira Loka di Yogyakarta.

Kebun binatang Gembira Loka di Yogyakarta sebagai salah satu jenis kebun binatang yang ada di Indonesia mempunyai fungsi dan tujuan sebagai tempat rekreasi, konservasi, penelitian dan edukasi, hal ini seperti yang di sampaikan oleh Tirtodiprojo:

Konsep Gembira Loka yang naturalistik, adalah sebagai wadah kegiatan rekreasi alami yang fungsi dan tujuannya sebagai tempat rekreasi, konservasi, penelitian dan edukasi, perkembangan ilmu zoology dan botani di Indonesia dan kesadaran masyarakat dalam merawat, menjaga dan melindungi flora dan fauna (Tirtodiprojo, 2008, p.44).

Kalimat tersebut mengandung makna bahwa kebun binatang Gembira Loka Yogyakarta berupaya melaksanakan perannya secara terencana dengan program-program yang nyata. Kebun Binatang Gembira Loka telah memulai langkah-langkah untuk mengembangkan dirinya sebagai sumber belajar bagi anak usia dini, siswa sekolah dasar, menengah, tingkat lanjut dan untuk remaja serta orang dewasa. Salah satu upaya yang dilakukan adalah pengembangan jaringan kerjasama kebun binatang dengan Pendidikan Tinggi. Jalinan yang dilakukan kebun binatang Gembira Loka Yogyakarta dan Jurusan Pendidikan Luar Sekolah Fakultas Ilmu Pendidikan Universitas Negeri Yogyakarta (PLS FIP UNY) adalah melalui pelaksanaan program pembelajaran luar sekolah, Selama ini pelaksanaan pembelajaran dilaksanakan oleh mahasiswa dan alumni PLS FIP UNY dalam memberikan materi dan pendampingan pada pengunjung dari masyarakat, khususnya PAUD, Anak SD, SMP, SMA dan Kelompok masyarakat. Berdasarkan pelaksanaan kegiatan tersebut dapat dimanfaatkan sebagai bagian dari akses dan asset yang cukup berharga dalam pengembangan laboratorium luar kampus dari jurusan Pendidikan Luar sekolah FIP UNY melalui wisata belajar.

Realisasi dari kerjasama yang terjalin tersebut memberikan konsekuensi bagi pihak Pendidikan Tinggi untuk mengembangkan konsep dan model yang dapat di jadikan acuan pedoman pelaksanaan pembelajaran sebagai fungsi pendidikan di Gembira Loka. Pada kajian ini akan difokuskan pada tema kebun binatang berperan sebagai sumber pendidikan, bukan karena peran yang lain 
diabaikan, tetapi langkah menentukan fokus kajian diharapkan mampu menghasilkan kajian yang mendalam dan memberikan manfaat pengembangan yang terfokus.

Program wisata belajar dirancang dengan melibatkan mahasiswa jurusan Pendidikan Luar Sekolah FIP UNY sebagai fasilitator belajar. Mahasiswa sebagai fasilitator belajar diharapkan mendapatkan pengalaman yang bermanfaat sebagai bagian peningkatan kemampuan lulusan sarjana PLS. Selain itu proses kegiatan wisata belajar di kebun binatang harapannya juga benarbenar terjadi proses pembelajaran dan pola interaksi yang mampu mengembangkan kemampuan dan pemahaman ilmu pengetahuan di bidang flora dan fauna bagi siswa dan warga masyarakat yang berkunjung, sehingga peran fasilitator sangatlah penting dalam pembelajaran luar sekolah atau kelas ini.

Kegiatan pembelajaran luar sekolah dan luar kelas (outing class) banyak dilaksanakan untuk mengembangkan kreativitas peserta didik. Kegiatan pembelajaran luar kelas bertujuan untuk mengembangkan kompetensi sosial dan moral peserta didik dikarenakan kegiatan ini dilakukan secara bersama-sama dan penuh rasa tanggung jawab sehingga dapat digunakan mengembangkan kemampuan peserta didik dan untuk menghilangkan kejenuhan. Banyaknya aktifitas yang dilakukan oleh peserta didik sangat memungkinkan peserta didik mengalami kejenuhan di sekolah. Melalui program outing class ini ternyata dapat menyalurkan kejenuhan siswa kepada hal-hal positif dan memberi semangat baru. Outing class juga mampu melatih anak untuk bisa memecahkan masalah yang dihadapinya. Menurut Moeslichatoen (2004, p. 36) "Masalah yang dihadapi oleh anak sehari-hari dapat bersifat masalah emosional, sosial maupun intelektual. Anak dapat menggunakan kegiatan bermain sebagai sarana untuk memecahkan persoalan intelektualnya dengan bermain anak dapat menyalurkan rasa ingin tahunya seperti bagaimana memasak air, mengapa pohon layu bila tidak diberi air, mengapa es mencair".

Berdasarkan observasi dan wawancara di Kebun Binatang Gembira Loka ditemukan Permasalahan yang terkait dengan: (1) Masih minimnya sumber daya manusia yang mampu mengelola kebun binatang Gembira Loka sebagai wisata belajar, (2) belum tersedianya desain model wisata belajar dikebun binatang Gembira Loka. (3) masih kurangnya materi outing class pada pelaksanaan pembelajaran luar sekolah di Gembira Loka Zoo. (4) Pendampingan yang dilakukan oleh Gembira Loka Zoo masih belum optimal, (5) masih kurangnya sarana dan prasarana yang dimiliki Gembira Loka Zoo untuk mendukung kegiatan outing class.

Keutamaan penelitian ini adalah telah teridentifikasi masalah dan potensi kebun binatang Gembira Loka dan jurusan pendidikan luar sekolah FIP UNY, maka model wisata belajar di kebun binatang Gembira Loka sebagai laboratorium luar kampus yang sudah didisain pun menjadi relatif mudah dilaksanakan, apalagi pendekatan penelitian ini juga melalui kemitraan, pendampingan dan dinamika kelompok. Jenis-jenis penelitian yang mengandalkan potensi sumber daya, sumber daya manusia dan dinamika kelompok diharapkan dapat membangun sistem pembelajaran secara berkelanjutan, mandiri dan bermakna bagi peningkatan kualitas pembelajaran luar sekolah di kebun binatang Gembira Loka. Adanya kerja sama antara pengelola Kebun Binatang Gembira Loka dengan Jurusan Pendidikan Pendidikan Luar Sekolah FIP UNY memberikan akses bagi mahasiswa untuk meningkatkan pengetahuan dan keterampilan dalam pengelolaan pembelajaran di luar kampus/sekolah. Hasil penelitian ini dapat membantu pengelola kebun binatang Gembira Loka dan dinas pariwisata mengenai wisata belajar setempat untuk membangkitkan kembali peran kebun binatang sebagai lembagai konservasi, rekreasi dan edukasi. Adanya program ini dilaksanakan melalui pendampingan pada pengunjung Gembira Loka dengan memanfaatkan koleksi bnatang, dokumentasi, lingkungan alam, tumbuhan, taman bacaan masayarakat dan aneka alat edukasi lain dalam mengelola wisata belajar.

\section{METODE}

Disesuaikan dengan kondisi yang sudah dilaksanakan. Pada tahap awal ini digali informasi tentang potensi dan masalah 
dalam mengembangkan model wisata belajar sebagai laboratorium luar kampus. Penelitian pengembangan ini dilaksanakan di kebun binatang Gembira Loka Yogyakarta. Dalam penelitian ini, data dikumpulkan dengan menggunakan metode forum group discution, wawancara mendalam, dokumentasi dan observasi. Data yang terkumpul dianalisis menggunakan teknik deskripsi kuantitatif dan kualitatif.

\section{HASIL DAN PEMBAHASAN}

Desain model wisata belajar di kebun binatang sebagai laboratorium luar kampus yang merujuk pada metode penelitian tindakan. Dari informasi yang diperoleh pada tahap pengumpulan data, selanjutnya peneliti mendesain produk yang berupa desain model wisata belajar di kebun binatang sebagai laboratorium luar kampus. Berdasar Peraturan Menteri Pendidikan dan Kebudayaan No. 049 Tahun 2014 tentang Standar Nasional Pendidikan Tinggi (SNPT) dan ditetapkannya kerangka Kualifikasi Nasional Indonesia (KKNI) oleh pemerintah melalui Perpres No. 8 Tahun 2012 sebagai acuan dalam penyusunan capaian pembelajaran lulusan dari setiap jenjang pendidikan secara nasional, lembaga pendidikan perlu melakukan kajian dan pengembangan kurikulum yang digunakan. Kurikulum dan perangkat daya dukungnya (labsite) sebagai alat utama dalam pelaksanaan sebuah program studi, senantiasa memerlukan perubahan, pemutakhiran, dan penyempurnaan. Sumber atau pendorong diperlukannya perubahan ini dapat berasal hasil dari: (a) tuntutan dunia kerja sebagai pengguna lulusan (stakeholder), (b) perkembangan ilmu pengetahuan, teknologi, dan seni, (c) tuntutan kebutuhan masyarakat, dan (d) lingkungan kebijakan.

Pendidikan luar sekolah dalam melaksanakan programnya banyak menggunakan pendekatan nonformal dan informal, mengharuskan lulusan pendidikan luar sekolah (sarjana) memiliki kompetensi sebagai pendidik dan tenaga kependidikan yang langsung memberikan layanan edukasional, dan juga memiliki kemampuan mengelola program kependidikan dan pemberdayaan masyarakat yang harus bekerjasama dengan orang lain dengan keahlian yang serumpun maupun keahlian lain yang memang dibutuhkan di masyarakat. Keahlian tersebut dalam pengembangan yang akan dilakukan dalam kajian kali ini adalah optimalisasi potensi mahasiswa untuk menggelola sebuah program non formal dalam mengembangan laboratorium yaitu menggelola program pembelajaran luar sekolah yang berada di Gembira Loka. Adapun desain dari model tersebut dapat dilihat pada Gambar 1.

Dari desain model Gambar 1 dapat dipaparkan sebagai berikut, tahap awal yang dilakukan adalah melakukan identifikasi masalah dan potensi. Pada tahap ini kegiatan yang dilakukan adalah mengidentifikasi potensi dan masalah yang dijadikan materi dan tujuan pembelajaran untuk memperoleh gambaran apa saja yang akan dimasukkan ke panduan paket-paket wisata belajar seperti; materi pembelajaran, mencari gambar, media yang cocok bahan dan alat yang sesuai dengan program wisata belajar.

Panduan pengembangan wisata belajar dalam hal ini memanfaatkan potensi Kebun Binatang Gembira Loka menjadi salah satu alternatif kontekstual yang dapat digunakan untuk mengoptimalkan interaksi antara fasilitator-peserta wisata belajardan motivasi peserta didik. Desain yang dikembangkan meliputi; menyiapkan bentuk kegiatan wisata belajar yang telah disepakati berdasarkan hasil indentifikasi masalah dan potensi Gembira Loka Zoo, Dalam membuat desain ini, dilakukan secara bersama antara pengembang, pemandu wisata belajar dengan staf pengelola program wisata belajar Gembira Loka Zoo. Dari desain tersebut dapat dijelaskan sebagai berikut. 


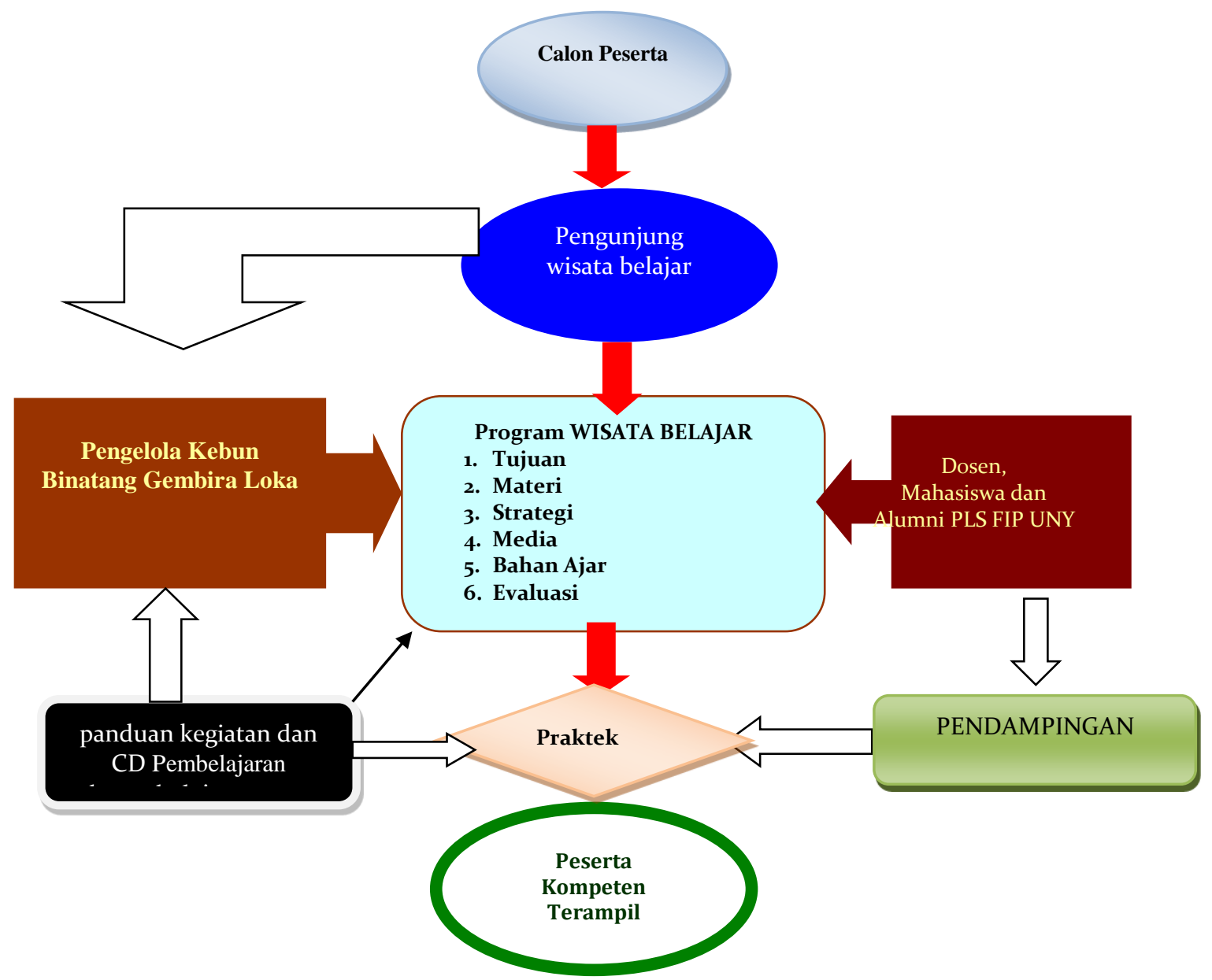

Gambar 1. Desain Model wisata belajar sebagai Laboratorium Luar

\section{Calon Peserta}

Calon peserta wisata belajar merupakan orang yang mengikuti program pengembangan pembelajaran luar sekolah melalui pembelajaran outing class dengan berbabagi variasi kegiatan pojok kreatif yang dapat memberikan kemudahan akses kepada anak, pelajar dan orang dewasa, agar dapat belajar secara nyata bagi Anak Usia Dini (AUD), Sekolah Dasar (SD), Sekolah Menengah Pertama (SMP) dan Sekolah Menengah Atas (SMA). dan komunitas masyarakat. Untuk menjaring calon peserta program wisata belajar, pengelola GL Zoo melakukan menjalin kerjasama dengan dinas pendidikan kabupaten/kota di Yogyakarta dan sosialisasi yang dilakukan oleh prodi PLS FIP UNY melalui forum-forum ilmiah.

\section{Pemilihan Peserta}

Pemilihan peserta dilakukan oleh pengelola Gembira Loka Zoo dengan menetapkan persyaratan bagi lembaga pendidikan dan komunitas masyarakat yang akan memanfaatkan program wisata belajar. Melalui kegiatan ini pengunjung yang berasal dari instansi sekolah atau komunitas masyarakat lain minimal ada 25 orang dapat menggunakan fasilitas ini. Kegiatan Wisata Belajar ini berupa kegiatan outing class dan berbagai kegiatan mainan lainnya yang menyajikan kegiatan wisata dan belajar. Kegiatan ini di dalamnya terdapat kegiatan berupa pojok kreatif yang hasil karyanya dapat dibawa pulang oleh peserta.

\section{Program Wisata Belajar}

Program wisata belajar di Gembira Loka Zoo dalam bentuk pelatihan pemandu, outing class, permainan, pojok kreatif dan pendampingan. Setiap program kegiatan dilakukan melalui tiga tahapan;

\section{Persiapan}

Tahap ini mempersiapkan pemandu, perangkat pembelajaran, tempat, media dan 
sumber belajar yang mendukung kegiatan yang akan dilakukan meliputi;

\section{Tujuan}

Kegiatan yang dilakukan dalam bentuk pelatihan dan pendampingan. Tujuan pelatihan dan pendampingan agara; (a) mahapeserta memiliki pengetahuan, keterampilan dan sikap positif dalam mengelola potensi Gembira Loka sebagai media dan sumber belajar, (b) dimilikinya kepedulian mahapeserta dan peserta program wisata belajar dalam pelestarian lingkungan dan hewan secara nyata.

\section{Materi}

Materi dalam program wisata belajar dalam bentuk pelatihan, outing class, pojok kreatif, permainan dan pendampingan dalam kegiatan wisata belajar meliputi; (a) penyambutan, (b) bina suasana, (c) zona flora, (d) zona fauna, (d) pojok kreatif (pop up, melukis gerabah, menanam bibit tanaman, mahkota hewan,dan mozaik), (e) recalling $\mathrm{dn}$ (f) refleksi (selengkapnya lihat di panduan)

\section{Strategi}

Strategi merupakan prosedur penataan cara-cara penyampaian materi dan penggalian informasi dalam mencapai tujuan pelatihan. Strategi pelatihan yang diterapkan dalam pelatihan ini meliputi; strategi problem solving, pembelajaran berbasis pada pengalaman, dan learning by doing. Metode yang digunakan; ceramah, permainan. diskusi kelompok, praktek, dan mentoring.

Langkah-langkah

Dalam setiap kegiatan wisata belajara dilakukan dengan tahapan sebagai berikut: (a) Pendahuluan, meliputi; bina suasana, motivasi, dan appersepsi. (b) Kegiatan inti; penyampaian materi, pengenalan bahan dan alat, prosedur praktek, praktek dan mentoring (pendampingan). (c) penutup mereview dan membuat kesimpulan.

\section{Pelaksanaan Program}

Pelaksanaan program wisata belajar dilakukan melalui pembelajaran luar sekolah di Gembira Loka Zoo sesuai dengan run done kegiatan yang sudah disusun sebelumnya. Peserta kegiatan wisata belajar harus memakai seragam dan tanpa didampingi oleh orang tua. Peserta yang mengikuti kegiatan ini dilatih untuk mandiri dalam memecahkan masalah yang diberikan oleh pemandu. Peserta diberikan materi dan keterampilan yang berguna untuk melatih otak dan ketrampilan motorik peserta.

Pelaksanaan Kegiatan Wisata Belajar dimulai dengan pembagian tugas yang dilakukan oleh pemandu. Hal ini memudahkan pemandu untuk mengatur jalannya kegiatan. Pemandu menyiapkan beberapa alat dan bahan yang akan digunakan dalam kegiatan wisata belajar di Gembira Loka Zoo. Pemandu yang mengikuti kegiatan wisata belajar di Gembira Loka Zoo sudah dibagi tugasnya masing-masing. Pembagian tugas bertujuan untuk memudahkan pelaksanaan kegiatan wisata belajar. Pelaksanaan kegiatan wisata belajar di Gembira Loka Zoo meliputi:

\section{Kegiatan Penyambutan}

Kegiatan wisata belajar di Gembira Loka Zoo selanjutnya adalah penyambutan yang dilakukan oleh pemandu dan badut di Gembira Loka Zoo. Kegiatan pada penyambutan ini pemandu berusaha mengenal lebih dekat dengan peserta agar peserta merasa lebih nyaman dengan pemandu sampai akhir kegiatan, sehingga peserta tidak merasa tertekan karena tidak mengenal dengan baik kepada pemandu. pelaksanaan pendampingan pembelajaran luar sekolah diawali dengan penyambutan peserta kegiatan. Setelah itu pemandu menjalin keakraban dengan peserta sehingga peserta akan merasa nyaman dengan kegiatan ini sampai akhir kegiatan. Peserta dapat memahami maksud kegiatan dengan baik dan dapat dijadikan pengetahuan yang baru dan dapat ditularkan ke temanteman maupun orang lain di luar lingkungan sekolah.

\section{Kegiatan Bina Suasana}

Kegiatan outing class yang diterapkan di Gembira Loka Zoo juga menggunakan kegiatan bina suasana. Kegiatan bina suasana ini dilakukan untuk pemanasan dan meningkatkan motivasi belajar peserta, sehingga dalam kegiatan selanjutnya tetap 


\title{
Jurnal Pendidikan dan Pemberdayaan Masyarakat, 4 (1), March 2017 - 96
}

\author{
S. Sujarwo, Ibnu Samsi, Lutfi Wibawa
}

dalam kondisi yang semangat dan mampu memahami materi yang diberikan. Adanya pengoptimalan dalam penyampaian materi akan menimbulkan rasa berkesan oleh peserta sehingga peserta mampu menangkap maksud dari materi yang disampaikan. Dalam kegiatan bina suasana peserta diajak untuk berinteraksi dan melakukan aktivitas gerak untuk menciptakan semangat dari dalam diri peserta.

Setelah melakukan kegiatan bina suasana peserta diarahkan ke tempat yang sudah disiapkan oleh pemandu sebelumnya. Tempat yang digunakan dalam kegiatan pojok kreatif berada di tanah lapang yang berada di dalam lingkungan Gembira Loka Zoo. Kegiatan pojok kreatif diawali dengan pengkondisian yang dilakukan pemandu terhadap peserta. Pengkondisian ini dimaksudkan untuk memudahkan pemandu dalam menyampaikan materi kegiatan pojok kreatif. Pengkondisian dilakukan dengan pelanpelan agar peserta mengikuti arahan yang diberikan oleh pemandu. Kegiatan pengkondisian ini dilakukan diawal kegiatan pojok kreatif.

\section{Kegiatan Wisata Belajar}

Wisata belajar merupakan kegiatan inti dari pelaksanaan pembelajaran luar sekolah di Gembira Loka Zoo. Kegiatan wisata belajar terdapat proses pembelajaran yang meliputi pojok kreatif, pembelajaran flora dan fauna. Hal tersebut menjadi ciri khas dari pelaksanaan pembelajaran luar sekolah di gembira Loka Zoo, sehingga secara tidak langsung peserta memperoleh pengetahuan baru dari wisata belajar yang diikuti. Kegiatan wisata belajar meliputi:

\section{Pembelajaran Pojok Kreatif}

Kegiatan wisata belajar selanjutnya adalah kegiatan pojok kreatif. Pada pojok kreatif ini peserta difasilitasi oleh pihak Gembira Loka Zoo untuk mengikuti kegiatan berupa ketrampilan tangan yang dilakukan oleh peserta sendiri. Hasil dari ketrampilan di pojok kreatif ini dapat dibawa pulang oleh peserta yang bertujuan agar orang tua peserta di rumah dapat mengetahui kegiatan apa yang dilakukan oleh anaknya di Gembira Loka Zoo. Melalui kegiatan pojok kreatif peserta dapat mengembangkan daya kreatifitasnya melalui tugas ketrampilan yang diberikan oleh pemandu. Peserta akan terdorong untuk mengikuti kegiatan pojok kreatif di lain hari.

Pemilihan dan penentuan jenis pojok kreatif disesuaikan dengan tingkat perkembangan peserta. Pemandu berperan dalam pemilihan pojok kreatif yang tepat dengan usia dan tingkat perkembangan peserta yang mengikuti kegiatan pembelajaran. Beberapa jenis pojok kreatif yang sudah diterapkan pada peserta pada saat Kegiatan Wisata Belajar antara lain pop-up, melukis gerabah, menanaman bibit tanaman, mahkota hewan, dan mozaik. jenis kegiatan yang sudah dilaksana di Gembira Loka Zoo adalah popup, melukis gerabah, mozaik, menamam bibit tanaman dan mahkota hewan. Jenisjenis kegiatan pojok kreatif yang dilaksanakan di Gembira Loka Zoo meliputi:

\section{Pop-up}

Kegiatan pojok kreatif pop-up memerlukan daya kreatif dari peserta. Mereka dilatih mengembangkan daya kreatifnya. Bahan yang digunakan dalam kegiatan ini berupa kertas karton yang sudah dipola oleh pemandu sebelumnya, lem, dan crayon. Peserta ditugaskan untuk berimajinasi dalam menciptakan pola gambar sesuai yang diinginkan oleh masing-masing pesertanya. Tujuan dari pembuatan pop-up ini untuk melatih dan memberi pengalaman peserta, karena pop-up ini biasa digunakan sebagai kartu ucapan hari raya maupun ulang tahun. Melalui kegiatan ini diharapkan peserta dapat membuat karya pop-up secara mandiri di rumah dan disalurkan ilmu pengetahuan ke teman yang lain.

\section{Melukis Gerabah}

Kegiatan ini dilakukan oleh peserta dengan menggunakan beberapa alat yang sudah disiapkan oleh pemandu dan pihak Gembira Loka Zoo. Alat dan bahan yang digunakan pada kegiatan ini adalah cat air dan gerabah (berbentuk mobil-mobilan atau hewan). Peserta ditugaskan untuk mewarnai gerabah dengan berbagai warna yang disediakan oleh pemandu kegiatan. Kegiatan ini bertujuan merangsang sensor motorik dan 
mengembangkan daya kreatifitas peserta. Melalui hasil karya yang dihasilkan dapat dilihat bakat dasar peserta tersebut dan menjadi tolak ukur bagi peserta untuk lebih mengembangkan bakatnya. Pihak Gembira Loka Zoo menyediakan fasilitas ini gratis sehingga peserta dapat membawa pulang hasil karyanya masing-masing.

\section{Menanam Bibit Tanaman}

Kegiatan penanaman bibit tanaman dilakukan jika ada permintaan dari pihak sekolah. Gembira Loka Zoo membantu menyiapkan alat dan bahan yang akan digunakan dalam Kegiatan Wisata Belajar. Alat dan bahan yang digunakan dalam kegiatan ini berupa tanah kompos, bibit tanaman, dan polybag. Melalui kegiatan ini peserta dilatih untuk melakukan penanaman bibit tanaman dengan baik dan benar sesuai materi yang disampaikan oleh pemandu. Kegiatan ini juga bertujuan untuk diterapkan di rumah dan dapat diperlihatkan ke orang tua masing-masing.

\section{Mahkota Hewan}

Kegiatan ini berupa mewarnai kertas yang berbentuk pola hewan yang ada di Gembira Loka Zoo.Tugas peserta mewarnai sesuai dengan yang diinginkan dan sesuai imajinasi masing-masing peserta. Perkembangan sensor motorik mampu dihasilkan dari kegiatan pembuatan mahkota hewan ini. Peserta juga mampu mengembangkan daya kreatifitasnya melalui kegiatan pembuatan mahkota hewan ini. Bahan yang digunakan dalam kegiatan ini berupa kertas karton, gunting, lem, dan crayon. Peserta menyelesaikan hasta karya berupa kertas yang berbentuk pola tangan dan diwarnai menggunakan crayon sesuai dengan yang diinginkan.

\section{Mozaik}

Kegiatan mozaik berupa kegiatan yang membutuhkan daya kreatifitas dan imajinasi yang dimiliki oleh peserta.Peserta menempelkan beberapa potongan kertas ke atas pola gambar yang sudah diberi lem. Potongan kertas digunting keci-kecil dan terdapat beberapa warna berbeda untuk menghasilkan perpaduan warna yang indah. Melalui kegiatan ini sensor motorik dan daya kreatifitas peserta dapat diasah, sehingga ke depannya kemampuan dalam mengembangkan pola pikirnya menjadi lebih baik.

Tahap selanjutnya adalah memberikan waktu pada peserta untuk mengembangkan daya kreatifitasnya sebaik mungkin dalam mmenyelesaikan hasta karya yang diberikan oleh pemandu. Peserta diberi kebebasan dalam mengerjakan hasta karya, namun harus sesuai dengan materi yang sudah dijelaskan oleh pemandu sebelumnya.

Kegiatan akhir pada kegiatan pojok kreatif ini adalah recalling. Kegiatan ini berfungsi untuk mengetahui seberapa banyak peserta memahami materi yang telaha diberikan oleh pemandu dalam kegiatan pojok kreatif.Kegaitan recalling pada kegiatan pojok kreatif ini juga berfungsi untuk menanam kembali materi yang sebelumnya tidak diingat oleh peserta.

\section{Pembelajaran Flora dan Fauna}

Kegiatan pembelajaran flora dan fauna ini pemandu menjelaskan tentang apa saja yang termasuk dalam golongan flora maupun fauna. Salah satu contoh kegiatan pembelajaran flora adalah pemandu mengajak peserta ke hutan buatan yang dimiliki oleh Gembira Loka Zoo.Peran pemandu dalam kegiatan ini adalah menjelaskan dan menyampaikan cara-cara menanam dengan baik. Kegiatan pembelajaran flora bertujuan untuk melatih peserta dalam melakukan penanaman sendiri, sehingga mereka dapat menanam bibit tanaman di rumah masingmasing dengan baik dan benar.

Kegiatan pembelajaran fauna peserta diajak berinteraksi langsung dengan beberapa fauna yang ada di Gembira Loka Zoo.Kegiatan pembelajaran fauna ini melatih peserta untuk menyayangi fauna yang ada di sekitarnya. Kegiatan ini berada pada kegiatan tour the Zoo yang dilaksanakan di Gembira Loka Zoo. Peran pemandu dalam kegiatan ini adalah memberikan kesempatan kepada peserta untuk berinteraksi dengan beberapa koleksi fauna di Gembira Loka Zoo. Kegiatan berinteraksi langsung dengan hewan bertujuan untuk melatih peserta agar lebih menyayangi binatang. Melalui kegiatan 


\section{Jurnal Pendidikan dan Pemberdayaan Masyarakat, 4 (1), March 2017 - 98}

S. Sujarwo, Ibnu Samsi, Lutfi Wibawa

tersebut peserta juga dapat memperoleh pengetahuan tentang fauna yang disentuhnya.

\section{Kegiatan Tour the Zoo}

Kegiatan yang selanjutnya adalah tour the Zoo. Kegiatan ini peserta diajak untuk melihat dan mengamati hewan-hewan koleksi dari Gembira Loka Zoo. Tahap ini pemandu bertugas untuk mengawasi dan menjelaskan secara umum binatang yang dilihat oleh peserta. Setiap pemandu bertanggung jawab mengawasi dan memperhatikan kelompok peserta kegiatan yang sudah dibentuk sebelumnya. Pengelompokan ini bertujuan untuk mempermudah mengatur pada saat tour the Zoo, karena banyak pengunjung regular dan juga dilewati kereta wisata Gembira Loka Zoo. Peran pemandu dalam kegiatan ini adalah memberikan penjelasan secara garis beras tentang fauna yang dilihat oleh peserta. Penjelasan yang disampaikan oleh pemandu bertujuan untuk memberikan pemaknaan terhadap fauna yang dilihat. Pemaknaan fauna ini bertujuan untuk menambah pengetahuan peserta dengan memberikan penjelasan secara langsung mengenai fauna yang dilihat peserta dapat memberikan pengetahuan baru. Peserta diberikan pengetahuan secara umum mengenai fauna yang dilihatnya dan mengajak peserta untuk menyampaikan pengetahuan yang sudah dimiliki peserta sebelumnya.

\section{Pendampingan}

Kegiatan pendampingan dilakukan pada saat praktek pembelajaran. Tugas pemandu dalam proses kegiatan wisata belajar melalui kegiatan pembelajaran luar sekolah saat berlangsung adalah melakukan pendampingan dan membantu peserta yang mengalami hambatan dalam menyelesaikan hasta karyanya. Saat kegiatan pembelajaran berlangsung terkadang ada peserta yang masih ragu dalam menyelesaikan hasta karyanya sehingga dibutuhkan pemandu untuk membantu peserta. Pemandu bertugas untuk melakukan pendampingan dan mendorong peserta untuk mengembangkan daya kreatifitasnya. Pemandu sudah dilatih untuk mendekati peserta agar peserta merasa nyaman jika berada di dekat pemandu sehingga peserta dapat mengerjakan hasta karya dengan percaya diri.

Media

Media yang dibutuhkan dalam kegiatan wisata belajar di GL Zoo sangat dipengaruhi jenis dan bentuk kegiatan yang dilakukan, tujuan dan kondisi peserta. Media yang dibutuhkan misalnya; Media cetak, ATK, LCD, Aneka Fauna, Aneka Flora, Cat, Kertas Karton, balon, Gerabah, Benang, dan media lain yang relevan.

\section{Bahan Ajar}

Bahan ajar diperlukan untuk memberikan panduan atau pedoman kepada peserta dalam mengikuti kegiatan outingbclass, pelatihan dan pelaksanaan praktek lapangan. Bahan ajar dalam kegiatan wisata belajar dalam bentuk panduan pembelajaran, panduan model pengelolaan wisata belajar yang disu-sun berdasarkan karakteristik dan potensi lokal.

Penilaian

Penilaian yang dimaksud pada kegiatan ini dilakukan dalam bentuk monitoring dan evaluasi kegiatan. Monitoring dilakukan selama kegiatan pelatihan (teori dan praktek), pelaksanaan sampai pada tahap pendampingan. Penilaian dilakukan bersama antara pengelola program dan peserta wisata belajar.

\section{Penutup}

Pada kegiatan penutup ini pemandu mengajak peserta melakukan refleksi terhadap aktivitas yang dilakukan. Mengambil makna edukatif dari setiap aktivitas yang dilakukan yang direfleksikan dalam kehidupan sehari-hari.

\section{Pembahasan}

Program wisata belajar merupakan program pengembangan pendidikan di luar sekolah (pendidikan non formal) melalui pembelajaran outing clas yang dapat memberikan kemudahan akses kepada anak agar dapat belajar secara nyata bagi anak usia dini (PAUD), sekolah dasar (SD), sekolah menengah pertama (SMP) dan sekolah menengah atas (SMA) dan masyarakat merupakan 
terobosan pengelola dalam mengembangkan model pembelajaran luar sekolah. Pembelajaran luar sekolah juga dapat dikembangkan ke dalam pendidikan formal melalui wisata belajar.

Model wisata belajar dilakukan melalui kegiatan pembelajaran luar sekolah. Dalam pelaksanaan kegiatan pembelajaran luar sekolah dilakukan melalui bentuk outing class, permainan, pojok kreatif dan pendampingan. Kegiatan wisata belajar memiliki tahaptahap yang disusun untuk memudahkan kegiatan pendampingan. Penyusunan tahapan yang baik akan meminimalisir hambatan. Kegiatan wisata belajar dilakukan mulai persiapan, pelaksanaan, pendampingan, permainan dan refleksi. Hal ini sejalan dengan pendapat Lobo, (2008, pp. 10-11) tahapan kegiatan pendampingan meliputi: (1) tahap persiapan, pada tahap ini pemandu dipersiapkan untuk melakukan pendampingan dalam tahap ini juga dilakukan persamaan persepsi antar pemandu. (2) tahap assessment, dalam tahap ini pengidentifikasian masalah dilakukan untuk mengetahui kebutuhan dan sumber daya yang dimiliki peserta kegiatan. (3) tahap perencanaan, pada tahap ini peserta kegiatan dilatih untuk memecahkan masalah yang dihadapinya dan ditugaskan untuk memecahkan masalah yang dihadapi. (4) tahap pemformulaan rencana aksi, (5) dalam tahap ini peserta kegiatan dikelompokkan untuk menentukan program apa yang akan mereka lakukan untuk mengatasi masalah yang ada. (6) tahap pelaksanaan kegiatan, pada tahap ini peserta merealisasikan perencanaan yang telah dibuat sebelumnya. (7) tahap evaluasi, pemandu ditugaskan untuk mengawasi jalannya kegiatan hal ini memudahkan untuk memonitor peserta apabila ada hal yang tidak diinginkan terjadi. (8) tahap terminasi, merupakan tahap pemutusan hubungan secara formal setelah kegiatan sudah terlaksana.

Penggunaan panduan model wisata belajar yang dilengkapi dengan panduan dalam uji coba lapangan sudah memenuhi kategori efektif dan layak digunakan dalam kegiatan pembelajaran wisata belajar di GL Zoo Hal ini sejalan dengan pernyataan Depdiknas (2008) bahwa dalam mengembangkan bahan belajar perlu memperhatikan hal-hal sebagai berikut: (1) struktur sosial ekonomi masyarakat sasaran, (2) keyakinan dan praktik kehidupan bermata pencaharian masyarakat sasaran, (3) perhatian dan permasalahan yang dihadapi masyarakat sasaran, (4) bahasa dan kemampuan komunikasi masyarakat sasaran, (5) lingkungan hidup masyarakat sasaran secara umum (pekarangan, rumah, makanan, teknologi yang dikenal, dan lain-lain), dan (6) kesukaan masyarakat sasaran.

Kegiatan pendampingan pembelajaran luar sekolah di Gembira Loka Zoo ada 4 tahap persiapan, perencanaan, pelaksanaan dan evaluasi. Kegiatan pembelajaran luar sekolah diawali dengan persiapan yang dilakukan oleh pemandu. Tahap persiapan ini pemandu menyiapkan segala hal yang mendukung jalannya kegiatan. Melalui kegiatan persiapan ini diharapkan dapat meminimalisir hambatan. Kegiatan mengidentifikasi dilakukan oleh pemandu untuk menentukan materi apa yang tepat sesuai dengan karakter dan usia peserta kegiatan. Hal ini memudahkan peserta kegiatan dalam memahami materi yang disampaikan oleh pemandu.Pelaksanaan inti dari kegiatan pembelajaran luar sekolah di Gembira Loka Zoo adalah pojok kreatif.

Kegiatan pojok kreatif merupakan kegiatan yang didalamnya terdapat ketrampilan yang melibatkan peserta secara langsung. Kegiatan pojok kreatif ini dilaksanakan di luar kelas agar peserta tidak jenuh. Sesuai dengan pendapat dari Moeslichatoen (2004, p. 15) memaparkan bahwa melalui kegiatan pengajaran di luar ruang secara langsung akan mendorong anak untuk memperoleh kesan yang sesuai dengan apa yang diamati, sehingga peserta dapat mengembangkan pola pikirnya dengan baik.

Kegiatan pojok kreatif yang ada di pembelajaran luar sekolah diawali dengan pengkondisian peserta, pembagian media dan peralatan, penjelasan materi, pendampingan dan pengawasan peserta saat kegiatan berlangsung, dan yang terakhir recalling. Kegiatan pojok kreatif yang dilaksanakan di luar ruang ini sesuai dengan pendapat Husamah (2014, p.54) mengenai kelebihan yang akan diperoleh dari kegiatan wisata belajar adalah peserta dapat memperoleh 


\section{Jurnal Pendidikan dan Pemberdayaan Masyarakat, 4 (1), March 2017 - 100}

S. Sujarwo, Ibnu Samsi, Lutfi Wibawa

pengalaman secara langsung sehingga kegiatan pembelajaran dapat bermakna, memperbanyak pengalaman dan pengetahuan peserta baik di dalam maupun di luar kelas, memberikan kesenangan peserta terhadap alam sekitarnya.

\section{SIMPULAN DAN SARAN}

\section{Simpulan}

Disain model wisata belajar di GL Zoo merujuk pada penelitian tindakan. Dari informasi yang diperoleh pada tahap pengumpulan data, selanjutnya peneliti mendesain produk yang berupa desain model wisata belajar, menyusun panduan kegiatan, panduan pendampingan, pelaksanaan dan refleksi. Untuk mendukung keberhasilan wisata belajar perlu adanya panduan yang dapat dijadikan acuan dalam kegiatan pembelajaran. Adapun komponen dalam desain model ini terdiri dari; (1) calon peserta, (2) memilih peserta, (3) Bentuk Kegiatan Wisata Belajar (penyambutan, bina suasana, tour to zoo, zona alam, pojok kreatif, permainan, dan refleksi) (4) Materi Kegiatan sesuai jenis kegiatannya, (5) media, (6) bahan Ajar, (7) penilaian, (8) sosialisasi program, (9) pelaksanaan program, (10) evaluasi program dan 11) pendampingan, Model ini dilengkapi dengan panduan kegiatan, panduan pembelajarn, dan panduan materi wisata belajar

\section{Saran}

Dalam pemanfaatan model wisata belajar disarankan sebagai berikut: (a) Dalam pelaksanaan kegiatan wisata belajar baik bagi pengelola program maupun pemandu diharapkan mempelajari dan memahami terlebih dahulu model wisata belajar yang dikembangan; (b) Untuk kegiatan wisata belajar diupayakan seluruh peserta dapat memiliki informasi yang lengkap dalam bentuk buku secara masing-masing supaya dapat terlibat aktif dalam berbagai kegiatan yang dilaksanakan; (c) Panduan ini dapat dimanfaatkan dalam penyelenggaraan program wisata belajar lain yang memiliki kekhasan yang sama

\section{Pengembangan Produk Lebih Lanjut}

Adanya pengembangan model wisata belajar di GL Zoo ini, maka perlu adanya tindak lanjut yang lebih mendalam untuk panduan dan materi pembelajaran yang sesuai dengan indikator pencapaian kompetensi yang lain. Model dan panduan wisata belajar yang dikembangkan belum sepenuhnya memenuhi kebutuhan wisata belajar di GL Zoo, sehingga perlu dilakukan penambahan untuk kompetensi dasar yang lain. Perlu adanya pengkajian ilmiah tentang implementasi hasil pengembangan model wisata belajar ini agar dapat digunakan secara lebih efektif.

\section{DAFTAR PUSTAKA}

Husamah. (2013). Pembelajaran luar kelas (Outdoor Learning). Jakarta. Pustaka Karya.

Lobo, A. N. (2008). Proses pendampingan wanita pekerja seks komersial dalam upaya pencegahan HIV/AIDS (Studi kasus di lokalisasi Tanjung Elmo Sentani oleh perkumpulan keluarga berencana Indonesia daerah Papua Provinsi Papua). Universitas Indonesia.

Moeslichatoen, M. (2004). Metode pengajaran di taman kanak-kanak. Jakarta: Rineka Cipta.

Rushforth, H., Vieuten, C. Van der, Shatzer, J., Jones, R., Mullee, M., Turnbull, J., ... Thomas, E. (2008). Reflections on a study tour to explore history taking and physical assessment education. Nurse Education in Practice, 8(1), 3140.

http://doi.org/10.1016/j.nepr.2007.02.0 04

Tirtodiprojo, dkk. (2008). Panduan satwa. Yogyakarta: Kebun Raya dan Kebun Binatang Gembira Loka 